\title{
Development of a highly efficient oil degumming process using a novel phosphatidylinositol-specific phospholipase $\mathrm{C}$ enzyme
}

\author{
Sebastián Cerminati ${ }^{1}$. Florencia Eberhardt ${ }^{1}$. Claudia E. Elena ${ }^{2} \cdot$ Salvador Peirú $^{1,2}$. \\ María E. Castelli ${ }^{1,2} \cdot$ Hugo G. Menzella ${ }^{1,2}$
}

Received: 4 October 2016 / Revised: 31 January 2017 / Accepted: 14 February 2017

(C) Springer-Verlag Berlin Heidelberg 2017

\begin{abstract}
Enzymatic degumming using phospholipase C (PLC) enzymes may be used in environmentally friendly processes with improved oil recovery yields. In this work, phosphatidylinositol-specific phospholipase C (PIPLC) candidates obtained from an in silico analysis were evaluated for oil degumming. A PIPLC from Lysinibacillus sphaericus was shown to efficiently remove phosphatidylinositol from crude oil, and when combined with a second phosphatidylcholine and phosphatidylethanolamine-specific phospholipase $\mathrm{C}$, the three major phospholipids were completely hydrolyzed, providing an extra yield of oil greater than $2.1 \%$, compared to standard methods. A remarkably efficient fed-batch Escherichia coli fermentation process producing $\sim 14 \mathrm{~g} / \mathrm{L}$ of the recombinant PIPLC enzyme was developed, which may facilitate the adoption of this cost-effective oil-refining process.
\end{abstract}

Keywords Enzymatic degumming · Phospholipid removal · Green chemistry $\cdot$ Phosphatidylinositol phospholipase C

Sebastián Cerminati and Florencia Eberhardt contributed equally.

Electronic supplementary material The online version of this article (doi:10.1007/s00253-017-8201-0) contains supplementary material, which is available to authorized users.

Hugo G. Menzella

hmenzella@ fbioyf.unr.edu.ar

1 CONICET y Departamento de Tecnología, Facultad de Ciencias Bioquímicas y Farmacéuticas, Universidad Nacional de Rosario (UNR), Instituto de Procesos Biotecnológicos y Químicos (IPROBYQ), Suipacha 531, 2000 Rosario, Argentina

2 Keclon S.A., Tucumán 7180, 2000 Rosario, Argentina

\section{Introduction}

In the last few years, there has been a constant increase in the demand for oils for use as a food and production of fuels. This demand has generated a need for cost-effective methods for removing contaminating phospholipids, known as "gums", during the refining process (Hammond et al. 2005). Traditionally, physical and chemical degumming methods have been used. More recently, developments were made to use enzymatic degumming, which possesses several advantages over chemical and physical methods such as minimal chemical waste and higher yields of refined oil (Dijkstra 2011; Hammond et al. 2005).

So far, different kinds of enzymes have been reported to be efficient for oil degumming, including type $\mathrm{A}$ and $\mathrm{C}$ phospholipases and glycerophospholipid/cholesterol acyltransferases. Among them, type $\mathrm{C}$ phosholipases (PLCs) are the preferred ones, since they provide a higher extra yield of oil compared to traditional methods, both by generating 1,2-diacylglicerol (DAG) from phospholipids, which is miscible with triacylglycerols (TAGs), and by releasing the TAGs trapped as a consequence of the reduced volume of gums. Additionally, PLCs do not generate free fatty acids as a product and therefore do not increase the acidity of the treated oil, which may negatively impact the downstream refining process of the oil and the final product (Clausen 2001; Dijkstra 2011; Kirk et al. 2002; Loeffler et al. 1999; Lyu et al. 2016; Segers and van der Sande 1990; Søe and Turner 2012; Yang et al. 2008).

Most of the PLCs reported in the literature for oil degumming have specificity for phosphatidylcholine (PC) and/or phosphatidylethanolamine (PE), which together represent $\sim 67 \%$ of the phospholipids present in soybean and canola oil (Borrelli and Trono 2015). Recently, we designed a novel PCPLC-Y, an engineered enzyme that can completely 
hydrolyze PC and PE and is therefore an interesting candidate for industrial-scale oil refining (Castelli et al. 2016).

Our laboratory has focused its efforts in discovering a PLC with specificity for phosphatidylinositol (PI), expecting to formulate this new enzyme in combination with PCPLC-Y in order to increase the efficiency of oil degumming. PI represents $\sim 24 \%$ of the phospholipids present in soybean oil. Thus, its hydrolysis with a specific PLC enzyme may generate additional DAGs and provide a further reduction of up to $\sim 91 \%$ of the total phospholipids present in soybean oil when used in combination with PCPLC-Y. If successful, this approach would produce a concomitant increase in the extra yield of recovered oil during the degumming stage, with a significant impact in the economics of the oil refining process. To the best of our knowledge, the characterization and use of PIPLC enzymes for oil degumming has not been reported in the literature.

Here, it is described for the first time the identification, characterization, and heterologous production in the scalable fed-batch fermentation process of an enzyme capable of hydrolyzing PI, as well as its successful use in combination with PCPLC-Y in oil degumming reactions. These results provide a way forward to improve the efficiency of enzymatic oil degumming processes at industrial scale.

\section{Materials and methods}

\section{Strains, plasmids, and growth conditions}

The bacterial strains and plasmids used in this study are listed in Table S1 (Supplementary Material). For general purposes, Escherichia coli was grown in Luria Bertani medium (LB) at $200 \mathrm{rpm}$ and $37^{\circ} \mathrm{C}$. The concentration of kanamycin and ampicillin used in the study were 50 and $100 \mathrm{mg} / \mathrm{L}$, respectively.

\section{DNA preparation, cloning, and transformation of Escherichia coli}

Restriction enzymes and T4 ligase were purchased from New England Biolabs. Plasmid DNA was prepared by using the Axygen Biosciences AxyPrep ${ }^{\mathrm{TM}}$ Plasmid Miniprep Kit.

The pKCN-His BAD plasmid was constructed from the backbone of the pET24a plasmid (Novagen). The araBAD promoter and the $a r a C$ gene were amplified using the primers pBADHis Fw (CAAAGATCTGATTCGTTACCAATTATG) and pBADHis Rv (AGGCATATGCAGTAGAGAGTTGC) and $\mathrm{pBAD} 33 / \mathrm{His}$ as template. The PCR product and the pET24a vector backbone were digested with $B g l$ II and NdeI and ligated to generate the vector $\mathrm{pKCN}$-His BAD.

Synthetic genes were synthesized by GenScript (NJ, USA), and the following GenBank accession numbers were assigned to them: Bacillus cereus PIPLC, KX685946; Aspergillus flavus, KX685947; Lysinibacillus sphaericus, KX685948; Streptomyces antibioticus, KX685949; and Enterococcus faecalis, KX685950 (Table 1). To clone them into the different pKCN-His BAD plasmid, the genes were synthesized with an NdeI restriction site at the $5^{\prime}$ end and an EcoRI site downstream their stop codon. The resulting plasmids are listed in Table S1.

Preparation of electrocompetent cells of E. coli was performed according to the protocols described by Sambrook et al. (1989). All plasmids were introduced into $E$. coli using a Bio-Rad Pulse Controller® apparatus according to the manufacturer's specifications.

\section{Protein expression, cell disruption, and SDS PAGE for PIPLC quantification}

For protein expression, E. coli BL21AI strains (Novagen) carrying the different $\mathrm{pKCN}$-His BAD-derived plasmids were grown overnight on LB. A 100-fold dilution of the cultures was made in the same medium and incubated with shaking at $37^{\circ} \mathrm{C}$. When the $\mathrm{OD}_{600}$ reached 0.5 , the cultures were induced with $0.4 \mathrm{~g} / \mathrm{L}$ of L-arabinose (Royal Cosun, Netherlands) for $6 \mathrm{~h}$ at $30^{\circ} \mathrm{C}$. To disrupt the cells, cells and the culture supernatant were separated by centrifugation. The cell pellets were resuspended in a buffer of $10 \mathrm{mM}$ sodium phosphate $\mathrm{pH} 7.0$

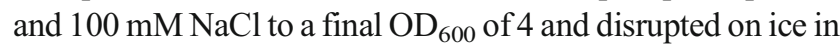
a GEX 600 Ultrasonic Processor. The cell extracts obtained after centrifugation were separated by SDS-PAGE on $12 \%$ gels, stained with Coomassie Brilliant Blue, and quantified by densitometry using a scanner. Bovine serum albumin (BSA, Sigma) was used as a standard. ImageJ software was used to quantify the scanned images.

\section{Enzyme purification and activity assays}

His-tagged PIPLCs were purified from E. coli BL21AI strains carrying the plasmid pKCN231, pKCN232, or pKCN233, cultured on LB broth and induced at $\mathrm{OD}_{600} 0.5$ with $0.4 \mathrm{~g} / \mathrm{L}$ of $\mathrm{L}$-arabinose at $30{ }^{\circ} \mathrm{C}$ with continuous shaking for $16 \mathrm{~h}$. Subsequently, cells were collected by centrifugation, washed, and resuspended in buffer A (15 mM sodium phosphate, $\mathrm{pH} 7.0,500 \mathrm{mM} \mathrm{NaCl}$ ) with $5 \mathrm{mM}$ imidazole, prior to disruption by sonication. After removing the cell

Table 1 PIPLC characteristics

\begin{tabular}{llll}
\hline Organisms & \% of identity & MW (Da) & GenBank accession number \\
\hline B. cereus & 100 & $34,542.1$ & KX685946 \\
A. flavus & 27 & $37,920.6$ & KX685947 \\
L. sphaericus & 67 & $44,339.6$ & KX685948 \\
S. antibioticus & 38 & $29,634.7$ & KX685949 \\
E. faecalis & 48 & $36,218.8$ & KX685950 \\
\hline
\end{tabular}


debris by centrifugation, the supernatants were passed through a $\mathrm{Ni}^{2+}$-NTA-agarose affinity column (GE Life Sciences) equilibrated with buffer A containing $5 \mathrm{mM}$ imidazole. The PIPLC proteins were recovered after washing with buffer A with $20 \mathrm{mM}$ imidazole, by elution with $0.5 \mathrm{M}$ imidazole and exhaustive dialysis in sodium phosphate buffer (15 mM pH 7 plus $10 \%$ glycerol; enzyme dilution buffer). All procedures were carried out at $4{ }^{\circ} \mathrm{C}$.

The fluorogenic substrate butyl-fluorescein-myo inositol (B-FLIP, Toronto Research Chemicals) was used for activity assays. For fluorescence measurements, the following buffer solutions were prepared: $4 \times$ assay buffer $(0.2 \mathrm{M}$ sodium acetate, $\mathrm{pH}$ 5.5; $4 \mu \mathrm{M}$ BSA) and enzyme dilution buffer. B-FLIP stock solution ( $2 \mathrm{mg} / \mathrm{mL}$ ) was made in deionized water and kept at room temperature. For fluorescence determinations, 200- $\mu \mathrm{L}$ aliquots of each sample, composed of $50 \mu \mathrm{L}$ of $4 \times$ buffer assay, $2 \mu \mathrm{L}$ of B-FLIP, $10 \mu \mathrm{L}$ of the corresponding enzyme dilution, and $138 \mu \mathrm{L}$ of $\mathrm{H}_{2} \mathrm{O}$, were applied in triplicate into a 96-well flat bottom black plate (Greiner Bio-One). Fluorescence was recorded using a Synergy Multi-Mode Microplate Reader (Bio-Tek) using $485 \pm 20$ - and $528 \pm 20$ $\mathrm{nm}$ filters for excitation and emission wave lengths, respectively. A 3-min time scan was first taken with all components except the enzyme. Then, $10 \mu \mathrm{L}$ of the enzyme dilutions was added and a second 3-min time scan was recorded.

\section{High cell density fermentation production process and protein formulation}

A seed culture of $E$. coli BL21AI harboring pKCN233 was prepared in a $1-\mathrm{L}$ Erlenmeyer flask containing $0.1 \mathrm{~L}$ of LB medium and cultivated at $37^{\circ} \mathrm{C}$ and $200 \mathrm{rpm}$ in a shaking incubator. Kanamycin was added at a concentration of $50 \mathrm{mg} / \mathrm{L}$ to maintain plasmid stability.

Fed-batch fermentations were carried out in 3- or 20-L fermenters (New Brunswick BioFlo 115 or BioFlo 415, USA) containing 1 or $12 \mathrm{~L}$ of semi-defined HM medium (Menzella et al. 2003), respectively. The temperature, stirring, and $\mathrm{pH}$ were maintained at $37^{\circ} \mathrm{C}, 1200 \mathrm{rpm}$, and 7 (by addition of $25 \% \mathrm{NH}_{4} \mathrm{OH}$ ), respectively. The level of dissolved oxygen was controlled at $30 \%$ of air saturation by changing the gas inflow ( 0.1 to $0.5 \mathrm{vvm})$ and the pure oxygen percentage when necessary. The feeding process was initiated when the glycerol present in the medium was exhausted. A solution containing $800 \mathrm{~g} / \mathrm{L}$ glycerol and $20 \mathrm{~g} / \mathrm{L} \mathrm{MgSO} \cdot \cdot 7 \mathrm{H}_{2} \mathrm{O}$ was added according to the feeding rate $(\mathrm{F}, \mathrm{mL} / \mathrm{h})$ determined by Eq. (1) (Lee 1996) in order to maintain the specific growth rate at $0.251 / \mathrm{h}$.

$F=\frac{\mu \mathrm{XoVo} e^{\mu t}}{\operatorname{SoY}_{X / S}}$ where $\mathrm{X}_{0}$ is the biomass concentration $(\mathrm{g} / \mathrm{L})$ when the feeding is started, $V_{0}$ is the initial volume $(\mathrm{L}), \mu$ is the desired specific growth rate $(1 / h), S_{0}$ is the glucose concentration in the feeding solution $(\mathrm{g} / \mathrm{L})$, and $\mathrm{Y}_{\mathrm{X} / \mathrm{S}}$ is the substrate yield.

Expression of the LS-PIPLC gene was induced when the $\mathrm{OD}_{600}$ reached 100 , by adding L-arabinose at a final concentration of $0.4 \mathrm{~g} / \mathrm{L}$. Afterwards, the feeding rate was maintained constant at $15 \mathrm{~mL} / \mathrm{h}$.

After the fermentation process, the cell culture was chilled and passed twice through a high-pressure homogenizer at 1000 bars (GEA Niro Soavi, PandaPLUS 2000). The cell debris was separated by centrifugation at $10,000 \mathrm{rpm}$ for $30 \mathrm{~min}$ in a bench centrifuge (Eppendorf 5804R) or in a continuous flow centrifuge (GEA Westfalia Separator FSD 1-06107) for 1- and 12-L fermentation volumes, respectively.

For the final formulation, LS-PIPLC was separated by ultrafiltration using a $10-\mathrm{kD}$ MWKO hollow fiber cartridge followed by diafiltration to formulate the enzyme in sodium phosphate buffer (15 mM, pH 7) plus $30 \%$ glycerol.

\section{Enzymatic oil degumming}

Oil degumming experiments were performed essentially as described previously using $3 \mathrm{~g}$ or $10 \mathrm{~kg}$ of crude soybean oil (Molinos Río de la Plata, Argentina) (Castelli et al. 2016; Ravasi et al. 2015). Briefly, for 3-g experiments, the crude oil was preincubated at $50{ }^{\circ} \mathrm{C}$ in a VP710 stirrer (V\&P Scientific Inc.) and the indicated amount of enzymes were emulsified using an Ultra-Turrax T8 Homogenizer and continuous stirring $(500 \mathrm{rpm})$ was maintained at $50{ }^{\circ} \mathrm{C}$ for $2 \mathrm{~h}$. For the $10-\mathrm{kg}$ experiments, crude oil was preincubated in a beaker and agitated with a three-bladed propeller-type impeller (70 $\mathrm{mm}$ diameter) to maintain continuous stirring during the reaction. One hundred milligrams of the LS-PIPLC enzyme and $50 \mathrm{mg}$ of formulated PLC-Y (Castelli et al. 2016), when indicated, in $30 \mathrm{~mL}$ of $50 \mathrm{mM}$ sodium citrate buffer $\mathrm{pH} 6$ were added to $10 \mathrm{~kg}$ of crude soybean oil. The mixture was emulsified using an Ultra-Turrax T65 Homogenizer, and continuous stirring ( $500 \mathrm{rpm})$ was maintained at $50^{\circ} \mathrm{C}$ for $2 \mathrm{~h}$. Finally, heat inactivation of the enzyme was done by incubation for $10 \mathrm{~min}$ at $85^{\circ} \mathrm{C}$, which ended the reaction. Control samples that lacked enzyme were prepared as well.

\section{Inorganic phosphate analysis}

For phosphate determination, the degummed oil was homogenized with an Ultra-Turrax T8 or T65, depending on the scale, and $200 \mathrm{mg}$ of the homogenized oil was mixed with $200 \mu \mathrm{L}$ of $1 \mathrm{M}$ Tris- $\mathrm{HCl} \mathrm{pH}$. Then, $800 \mu \mathrm{L}$ of water was added, incubated for $1 \mathrm{~h}$ at $37^{\circ} \mathrm{C}$ with constant agitation, and centrifuged for $5 \mathrm{~min}$ at $14000 \times \mathrm{g}$. Forty-five microliters of the aqueous phase was recovered and treated with $0.3 \mathrm{U}$ of calf 
intestinal phosphatase (Promega, WI, USA) for $1 \mathrm{~h}$ at $37^{\circ} \mathrm{C}$, following the manufacturer's instructions. Finally, inorganic phosphate was determined according to the method of Sumner (Sumner 1944). Briefly, $45 \mu \mathrm{L}$ of the sample containing the inorganic phosphate was mixed with $455 \mu \mathrm{L}$ of $5 \%$ TCA and with $500 \mu \mathrm{L}$ of color reagent $\left(4 \% \mathrm{FeSO}_{4}, 1 \%\left(\mathrm{NH}_{4}\right)_{6} \mathrm{MoO}_{24}\right.$. $\left.\mathrm{H}_{2} \mathrm{O}, 3.2 \% \mathrm{H}_{2} \mathrm{SO}_{4}\right)$. Spectrophotometric readings were made at $700 \mathrm{~nm}$ in a Novaspect III apparatus (Amersham Bioscience), and the micromoles of inorganic phosphate in the sample were calculated from a standard curve containing 0.025 to $0.25 \mu \mathrm{mol}$ of inorganic phosphate.

\section{NMR analysis of crude and PLC-treated oil}

NMR analysis was performed essentially as described previously (Ravasi et al. 2015). Briefly, $300 \mathrm{mg}$ of control or enzyme-treated oil samples were extracted with $900 \mu \mathrm{L}$ of NMR solution (100 mM Tris-HCl pH 10.5, 50 mM EDTA, $2.5 \%$ sodium deoxycholate) for $1 \mathrm{~h}$ at $37^{\circ} \mathrm{C}$ with constant agitation and the resulting aqueous phase was extracted with $600 \mu \mathrm{L}$ hexane. Finally, $50 \mu \mathrm{L}$ of $\mathrm{D}_{2} \mathrm{O}$ was added to the aqueous phase. The profile of ${ }^{31} \mathrm{P}$ NMR phospholipids was acquired using a Bruker 300 Ultrashield equipment.

\section{Extra yield determination}

In order to measure the extra yield of oil gained from the enzymatic treatment of crude oil, $10 \mathrm{~kg}$ of oil treated with enzyme or buffer was centrifuged at $3000 \times g$ for 5 min after the reactions were finished. The remaining wet gums were weighted, and the \%DAGs were determined following the AOCS-recommended method (CD 11-d-96), as previously described (Ravasi et al. 2015).

\section{Results}

\section{Gene selection, design, and synthesis}

PIPLCs are ubiquitous enzymes that catalyze the cleavage of the phosphodiester bond of inositol phospholipids, producing a water-soluble myo-inositol 1,2-cyclic phosphate or myoinositol 1-phosphate, and oil-soluble DAGs (Low 1989). Most of the identified PIPLCs are intracellular enzymes that participate in signal transduction pathways of higher eukaryotic organisms (Smrcka et al. 2012). Among bacteria, the B. cereus PIPLC has been extensively studied and its structure has been determined (Birrell et al. 2003; Heinz et al. 1995; Heinz et al. 1996). In order to find candidates capable of tolerating the harsh conditions used in industrial oil degumming, such as high temperature, a first approach was made by looking for microbial enzymes from thermophiles that have been naturally selected to tolerate extreme environmental conditions. Unfortunately, the search for PIPLC enzymes using BLAST analysis with $B$. cereus PIPLC (WP 001060370.1) as a query against known thermophile organisms [http://www-archbac.u-psud.fr/ genomics/phylotaxBlast.html (Altschul et al. 1997)] did not retrieve any candidate. However, several microbial PIPLC genes that code for secreted proteins, which are generally more stable at harsh environmental conditions, were identified using BLAST analysis against microbial proteins. From this search, three bacterial sequences from $L$. sphaericus (EON73549.1), S. antibioticus (BAG41445.1), and E. faecalis (WP_002408293.1) were selected. Additionally, a PIPLC from A. flavus (XP_002374318.1) was also chosen, since this genus is a rich source of enzymes used in a variety of industrial processes (Su et al. 2012; Ward 2012). All of these proteins possess at least $25 \%$ of identity with $B$. cereus PIPLC (Table 1), and they all have conserved catalytic amino acid sequences (Fig. S1) (Heinz et al. 1995). With the exception of A. flavus, all of these proteins possess an $N$-terminal signal sequence recognized by the Sec secretion system, as determined by Phobius software (http://phobius.sbc.su.se/).

Next, the four predicted mature proteins along with the sequence of $B$. cereus PIPLC were reverse translated and codon optimized for expression in E. coli, using a codon randomization algorithm (Menzella 2011). The resulting sequences were synthesized and cloned into the pKCN-His BAD plasmid under the control of the L-arabinose-inducible $\mathrm{BAD}$ promoter.

\section{Recombinant expression in $E$. coli and activity assays}

In order to determine whether the five constructs expressed the corresponding PIPLC proteins, the recombinant plasmids were transformed into E. coli $\mathrm{BL} 21 \mathrm{AI}$, and the soluble and insoluble fractions of the induced cell lysates were analyzed by SDS-PAGE. Four out of the five synthetic genes were successfully expressed, i.e., the PIPLCs from $B$. cereus (pKCN231), A. flavus (pKCN232), L. sphaericus (pKCN233), and S. antibioticus (pKCN234), although the latter product appeared only in the insoluble fraction (Fig. 1). The recombinant enzymes from B. cereus, A. flavus, and L. sphaericus were next purified using a $\mathrm{Ni}^{2+}$ resin and tested for PIPLC activity using the fluorogenic substrate B-FLIP, which when hydrolyzed by the PIPLC enzymes releases fluorescein. PIPLC activity was detected only for the B. cereus and L. sphaericus enzymes (BC-PIPLC and LSPIPLC, respectively), but not for A. flavus PIPLC (AFPIPLC) (Fig. 2a). It is worth noting that the concentration of BC-PIPLC needed to hydrolyze the B-FLIP was 1000 -fold lower than the concentration needed to obtain the same extent of hydrolysis using LS-PIPLC (pM vs. nM), reflecting differences in the affinity of the two proteins for this substrate. Although this assay in an aqueous environment is useful to 


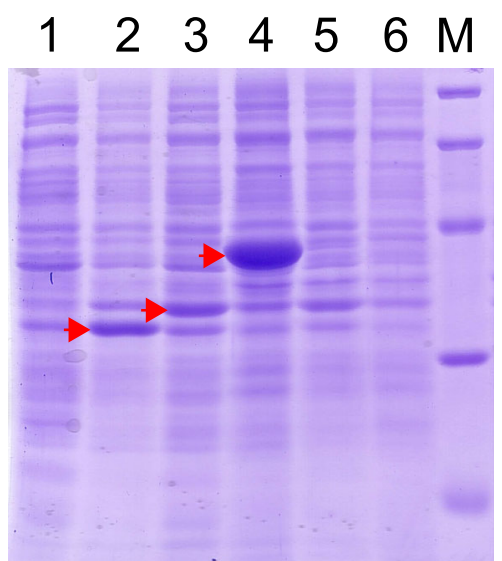

Fig. 1 PIPLC expression analysis. SDS-PAGE analysis of disrupted $E$. coli culture supernatants (left) and pellets (right) carrying plasmids pKCN231 (PIPLC B. cereus, $34.5 \mathrm{kDa}$, lane 2), pKCN232 (PIPLC A. flavus, $37.9 \mathrm{kDa}$, lane 3), pKCN233 (PIPLC L. sphaericus,

determine the ability of the enzymes to hydrolyze PI, it does not give any information about the suitability of the proteins for phospholipid hydrolysis when treating oil (Castelli et al. 2016). In order to assess this, the three candidates were evaluated for the ability to degum crude soybean oil in a 3-g scale using 5,10 , and $15 \mu \mathrm{g}$ of enzymes per gram of crude oil at $50{ }^{\circ} \mathrm{C}$ for $2 \mathrm{~h}$ (Ravasi et al. 2015). The activity of the phospholipase $\mathrm{C}$ enzymes was measured with a sensitivity assay based on the quantification of inorganic phosphate by a

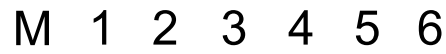

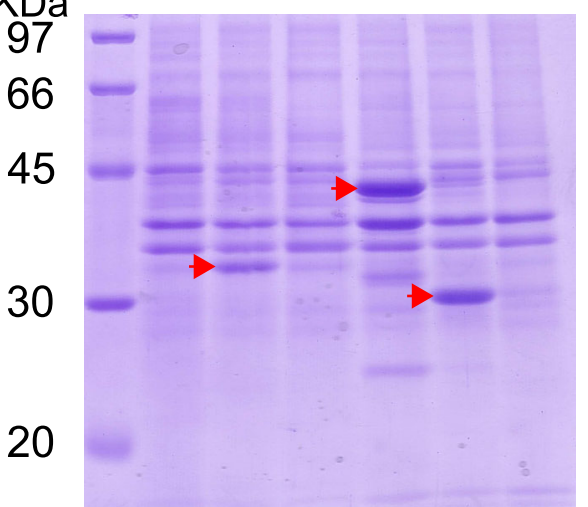

$44.3 \mathrm{kDa}$, lane 4), pKCN234 (PIPLC S. antibioticus, $29.6 \mathrm{kDa}$, lane 5), and pKCN235 (PIPLC E. faecalis, $36.2 \mathrm{kDa}$, lane 6). Lane 1 corresponds to $E$. coli carrying the empty vector. $M$ stands for molecular weight marker. Arrows indicate the corresponding PIPLC protein

colorimetric method. The assay consists in the recovery of the polar head groups from hydrolyzed phospholipids in oil by aqueous extraction, and their hydrolysis by an alkaline phosphatase to generate inorganic phosphate (Sumner 1944). Despite the differences in activity observed with the fluorogenic substrate, both BC-PIPLC and LS-PIPLC behaved similarly in oil degumming experiments, reaching a maximum of hydrolysis at $10 \mu \mathrm{g}$ of enzyme per gram of crude oil (Fig. 2b). Once again, no hydrolysis was detected when
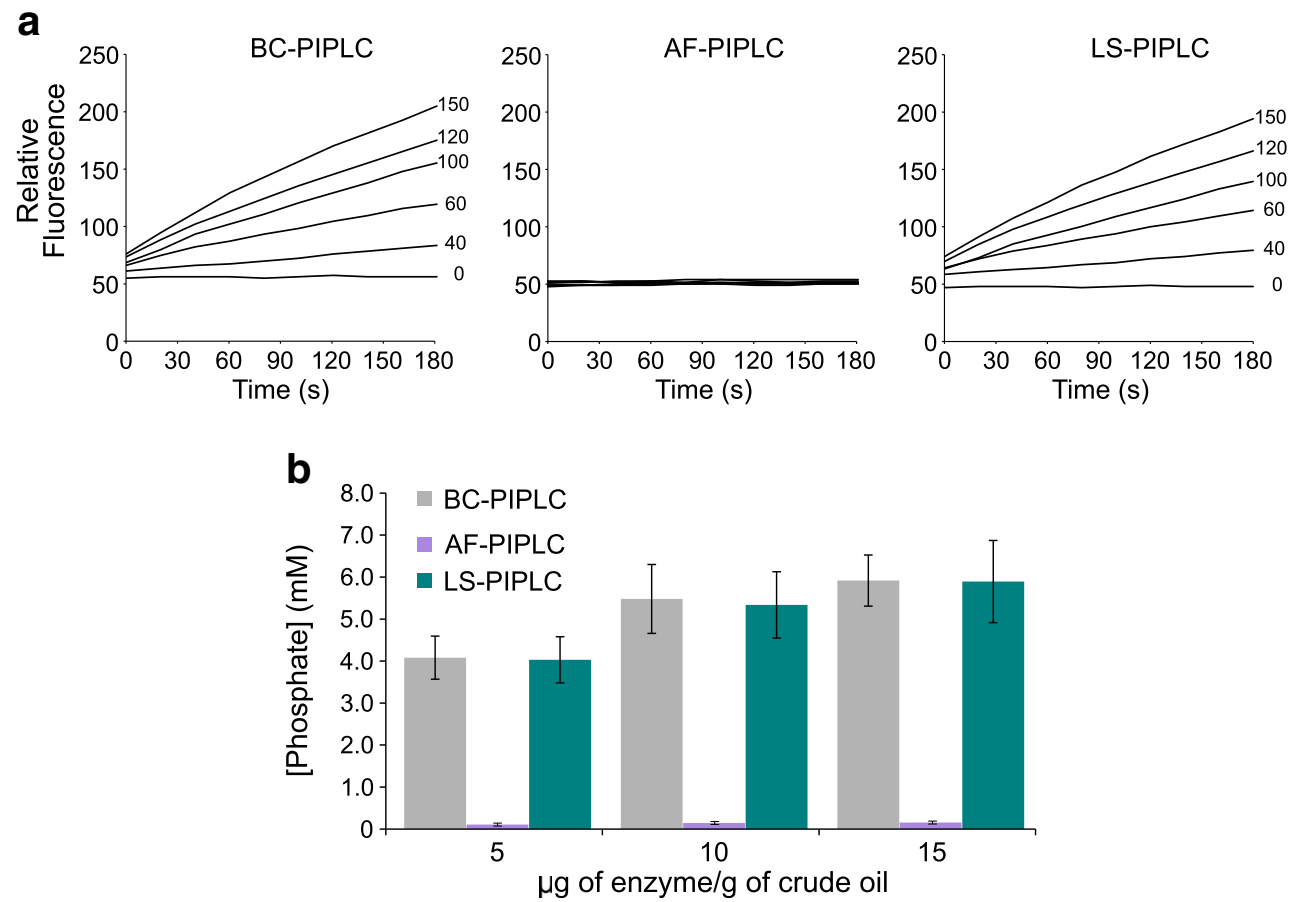

Fig. 2 PIPLC activity analysis. a Fluorescence emission intensity in arbitrary units at $520 \mathrm{~nm}$ for the cleavage of butyl-FLIP by purified BC-PIPLC, AF-PIPLC, and LS-PIPLC measured as a function of time. The lines are continuous sets of data points. The numbers at the right of each curve indicate the concentrations of enzyme (pM for BC-PIPLC;
$\mathrm{nM}$ for AF-PIPLC and LS-PIPLC) used in the assays. b Activity of the PIPLC proteins determined in crude soybean oil as a function of phosphate concentration. The concentrations used of each PIPLC were 5,10 , and $15 \mu \mathrm{g}$ per gram of crude oil. The results are expressed as means and standard deviations of at least three independent experiments 
AF-PIPLC was used for oil degumming, confirming the lack of activity of this protein.

\section{Fed-batch fermentation process design}

For most industrial enzymes, the manufacturing cost is a critical factor and high protein expression levels are desired to obtain high productivity (Menzella 2011; Welch et al. 2009). As shown in Fig. 1, the levels of LS-PIPLC expression are 2.5 times higher than those of BC-PIPLC, as determined from SDS-PAGE densitometry. Since both enzymes exhibited similar activity when employed at equal concentrations to remove gums from crude oil, LS-PIPLC presents, in principle, a clear advantage to develop a cost-effective manufacturing process in E. coli.

With this purpose in mind, a fed-batch fermentation process was developed in a 3-L lab scale bioreactor, using the recombinant strain $\mathrm{pKCN} 233$ expressing the LS-PIPLC under the pBAD promoter. This strain was grown at $37^{\circ} \mathrm{C}$ in $1 \mathrm{~L}$ of semi-defined medium using glycerol as a carbon source. Figure 3 shows that expression of LS-PIPLC at the time of induction was approximately $3.5 \mathrm{~g} / \mathrm{L}$, as a consequence of the promoter leakiness, and the production of the protein increased continuously until it reached a maximum titer of $14 \mathrm{~g} / \mathrm{L}$ after $12 \mathrm{~h}$ post induction. LS-PIPLC productivity, the growth profile, and glycerol consumption remained unaltered in more than 10 different fermentation experiments. These results are summarized in Table 2.

In order to further reduce manufacturing costs, the production of LS-PIPLC was analyzed using raw glycerol derived from biodiesel plants as a carbon source. Identical results were obtained. The process was also scaled up using a 20 -L bioreactor, and the same productivity was obtained (Table 2).

\section{Enzymatic oil degumming}

To evaluate the efficiency of the recombinant LS-PIPLC produced in high cell density $E$. coli fermentations for edible oil treatment, pilot-scale degumming reactions were designed, simulating the conditions used at industrial scale (Ravasi et al. 2015). With this purpose, the LS-PIPLC was used to assess its efficiency for oil degumming. Ten kilograms of crude soybean oil containing $2.5 \%$ phospholipids (1000 ppm phosphate) was mixed with $100 \mathrm{mg}$ of recombinant LSPIPLC. The resulting mixture was emulsified with a highshear mixer and incubated at $50{ }^{\circ} \mathrm{C}$ for $2 \mathrm{~h}$. The time course of the reaction was followed by determining the phosphate concentration. After $1 \mathrm{~h}$ of reaction, the concentration of phosphate generated reached a maximum value of $5.9 \pm 0.6 \mathrm{mM}$, corresponding to the expected amount for the complete hydrolysis of PI present in the crude soybean oil (Fig. 4). The remaining phospholipid fraction of the treated oil was next separated and analyzed by NMR. The spectrum shown in Fig. 5b

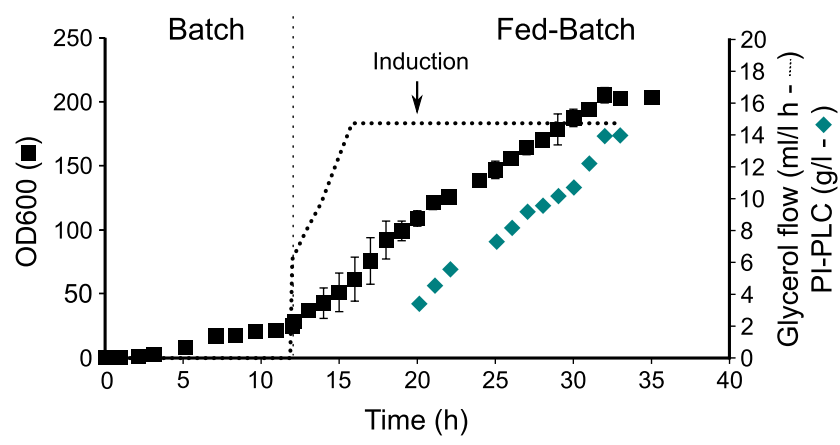

Fig. 3 Fed-batch process development for LS-PIPLC production. Time course of LS-PIPLC total protein concentration (diamonds), biomass (squares), and glycerol flow (gray line) during fed-batch fermentation in the 2-L fermenter with a semi-defined medium. Glycerol was used as the sole carbon source, and L-arabinose was used as inducer

confirms the complete hydrolysis of PI and the appearance of a new peak corresponding to its hydrolysis product, inositol phosphate (P-Ino).

In order to develop an enzymatic method to hydrolyze the three major phospholipids present in crude oil, a first approach was made by determining the mixing ratio of the enzymes needed for optimal oil degumming by measuring the phosphate produced after treatment with different concentrations of PCPLC and LS-PIPLC. Table 3 shows that the maximum phosphate concentration obtained was achieved with 5 and $10 \mu \mathrm{g}$ of PCPLC and LS-PIPLC per gram of crude oil, respectively, which is equivalent to the concentration of maximum PC/PE (Castelli et al. 2016) and PI hydrolysis determined for each enzyme separately. Thus, as a proof of concept, the same reaction conditions were tested for oil degumming in a 10-kg scale using LS-PIPLC in combination with $50 \mathrm{mg}$ of PLC-Y (Castelli et al. 2016). After a 2-h reaction, the NMR spectra of the enzyme-treated oil showed that the peaks corresponding to PC and PI are no longer detectable, while $90 \%$ of PE is hydrolyzed (Fig. 5c). On the other hand, the signals corresponding to the hydrolysis products phosphocholine (P-Cho), phosphoethanolamine (P-Et), and P-Ino could be detected (Fig. 5c).

From $10 \mathrm{~kg}$ of crude oil, $519 \mathrm{~g}$ of wet gums was recovered after centrifugation of the enzyme-treated oil, while $732 \mathrm{~g}$ was obtained from a control to which no enzyme was added, providing a $2.13 \%$ extra yield of oil recovered after treatment in comparison to traditional aqueous degumming methods. Here, $1.31 \%$ corresponds to DAGs generated by the hydrolysis of phospholipids and $0.82 \%$ corresponds to TAGs released from the gums. These results indicate the feasibility of combining LS-PIPLC and PLC-Y to obtain a superior oil degumming process and set the basis for scaling up the process. It is important to consider that crude vegetable oil is a complex mix of triglycerides, phospholipids, sterols, tocopherols, galactolipids, free fatty acids, metallic traces, and other minor compounds (Hammond et al. 2005). Gums are mainly composed by phospholipids, but they also contain other oil- 
Table 2 Fermentation parameters

\begin{tabular}{llll}
\hline Carbon source & Glycerol pro analysis & \multicolumn{2}{l}{ Crude glycerol } \\
\hline Fermentation volume & $1 \mathrm{~L}$ & $1 \mathrm{~L}$ & $12 \mathrm{~L}$ \\
Final OD600 & $224 \pm 13$ & $225 \pm 21$ & $206 \pm 12$ \\
PIPLC (g/L) & $14.6 \pm 0.6$ & $13.6 \pm 0.2$ & $15.3 \pm 1.3$ \\
Productivity (g/L/h) & $0.50 \pm 0.04$ & $0.47 \pm 0.03$ & $0.49 \pm 0.04$ \\
Residual glycerol (g/L) & $0.5 \pm 0.1$ & 0 & $2.0 \pm 0.5$ \\
Fermentation process time (h) & $29 \pm 2$ & $29 \pm 1$ & $31 \pm 1$ \\
\hline
\end{tabular}

insoluble compounds as well as entrapped TAGs. In this work, wet gums were obtained by centrifugation of water- or enzyme-treated oil, and the water used for degumming remains in this oil-insoluble fraction, representing 40 or $60 \%$ of the weight of the water- or enzyme-treated gums, respectively. In addition, enzyme-treated gums contain phospholipid hydrolysis products. This explains the apparent large amount of gums obtained after removing $91 \%$ of phospholipids.

\section{Discussion}

Enzymatic oil degumming is rapidly replacing traditional degumming methods because it offers an extra yield in oil recovery and is a more environmentally friendly method. The increased oil recovery is a result of both the concomitant generation of 1,2-DAG by the enzymatic activity, which is miscible with the TAGs, and the release of entrapped TAGs (Dijkstra 2011) by the reduced volume of the generated gums. PCPLCs are the most extensively used enzymes for enzymatic oil degumming as they hydrolyze $\mathrm{PC}$ and $\mathrm{PE}$, which represent $67 \%$ of phospholipids present in crude soybean oil (Dijkstra 2011; Loeffler et al. 1999; Søe and Turner 2012; Yang et al. 2008). However, a significant proportion of the phospholipids, composed by PI (24\%) and PA (9\%), remain in the gums. Thus, there is a need for the development of new enzymes to broaden the specificity of the degumming process

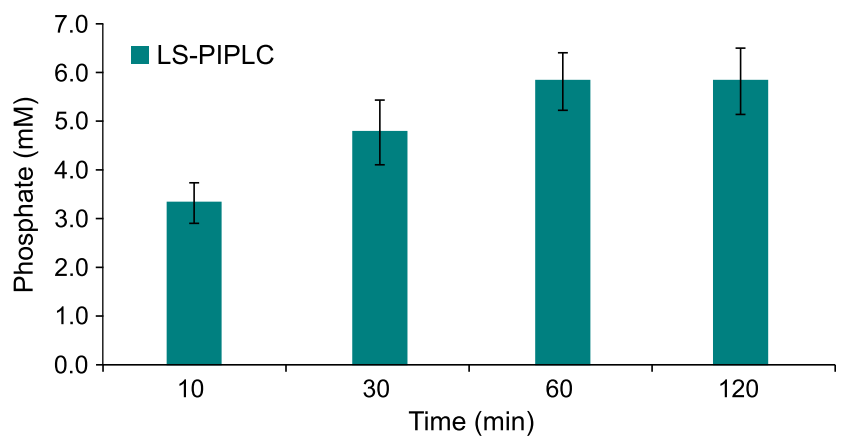

Fig. 4 Time course hydrolysis analysis. Activity of LS-PIPLC determined in crude soybean oil as a function of phosphate concentration. At the times indicated, samples of oil treated with $10 \mu \mathrm{g}$ of LS-PIPLC per gram of crude oil were taken and the concentrations of phosphate were determined. The results are expressed as means and standard deviations of at least three independent experiments mediated by PCPLCs in order to improve its efficiency. As PI represents $72 \%$ of the remaining phospholipids present in PCPLC-treated gums, PIPLC is an attractive candidate to fulfill that goal.

Both eukaryotic and prokaryotic PIPLC enzymes have been extensively studied, because of the importance of PI in cell signaling and pathogenesis. The eukaryotic PIPLCs are in general large, multimeric proteins with several domains involved in different aspects of the protein functionality, for example, the $\mathrm{PH}$ domains required for membrane association of the protein (Balla et al. 2012; Kuksis 2003; Low 1989). These are undesirable characteristics for producing a protein conceived for such an industrial process. On the other hand,
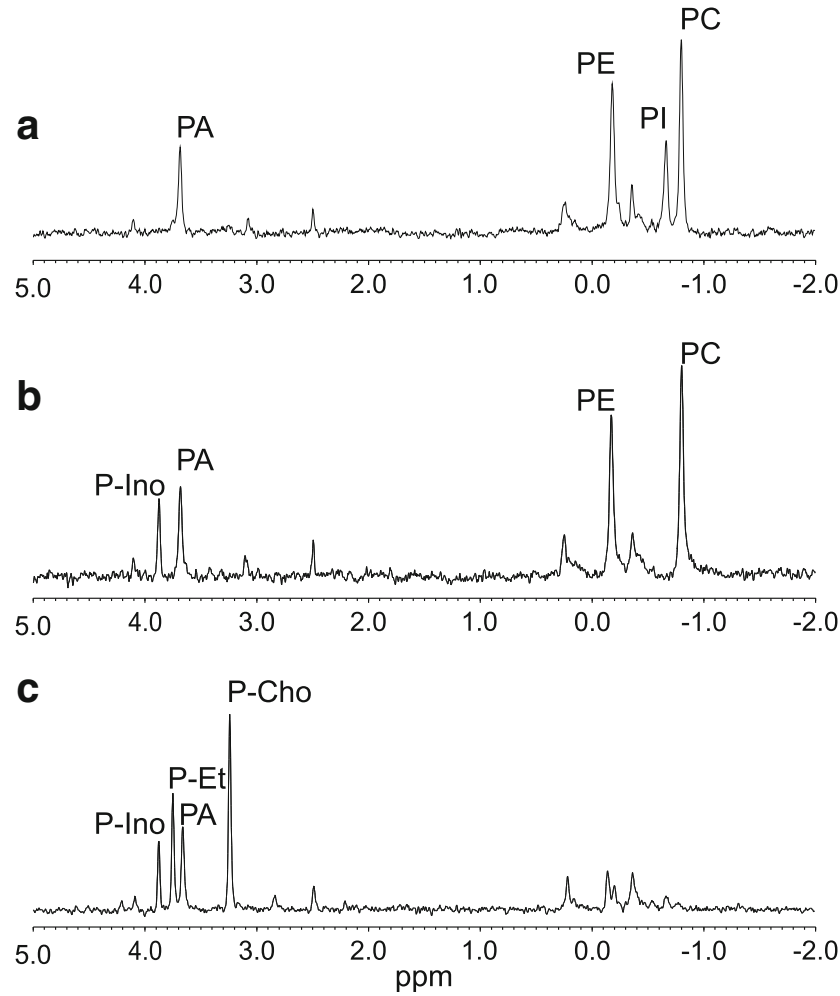

Fig. 5 LS-PIPLC-mediated hydrolysis of PI. NMR spectra for crude soybean oil to which no enzyme was added as a control (a), with $10 \mu \mathrm{g} / \mathrm{g}$ of crude oil of LS-PIPLC produced in E. coli (b), or with the combined use of 10 and $5 \mu \mathrm{g} / \mathrm{g}$ of crude oil of LS-PIPLC and PLC-Y, respectively. $P C$ phosphatidylcholine, $P E$ phosphatidylethanolamine, $P I$ phosphatidylinositol, $P A$ phosphatidic acid, $p C h o$ phosphocholine, $p E t$ phosphoethanolamine, $P$-ino phosphoinositol 
Table 3 Ratio of the enzymes needed for optimal oil degumming

\begin{tabular}{|c|c|c|c|c|}
\hline \multirow[t]{2}{*}{ PCPLC $^{\mathrm{a}}$} & \multicolumn{4}{|l|}{ LS-PIPLC $^{\mathrm{a}}$} \\
\hline & 0 & 2.5 & 5 & 10 \\
\hline 1.25 & ND & $16.0 \pm 0.1^{\mathrm{b}}$ & ND & $12.8 \pm 0.5$ \\
\hline 2.5 & $\mathrm{ND}$ & ND & $18.3 \pm 0.3$ & $15.8 \pm 0.3$ \\
\hline 3.75 & ND & ND & ND & $19.7 \pm 0.2$ \\
\hline 5 & $18.1 \pm 1.7$ & $19.2 \pm 0.5$ & $20.9 \pm 1.3$ & $22.9 \pm 0.5$ \\
\hline
\end{tabular}

${ }^{\text {a }}$ Enzyme concentrations are expressed in micrograms of enzyme per gram of crude oil

${ }^{\mathrm{b}}$ Phosphate concentration (mM). The results are expressed as means and standard deviations of at least three independent experiments

microbial PIPLCs are monomeric extracellular enzymes with molecular weights that do not generally exceed $50 \mathrm{kDa}$, naturally adapted to work in more severe environmental conditions, features that make them suitable for their implementation in an oil degumming process (Griffith and Ryan 1999). Among those enzymes, B. cereus PIPLC has been extensively studied. It has been crystallized with its substrate, and its mechanism of action is well understood (Heinz et al. 1995). In this study, five different PIPLC were selected, all containing the catalytic amino acids conserved and spanning at least $25 \%$ identity with $B$. cereus PIPLC. Four out of the five proteins were expressed in E. coli, i.e., BC-, AF-, LS, and SA-PIPLC (S. antibioticus), but not EF-PIPLC (E. faecalis) (Fig. 1). Since the E. coli envelope lacks phosphatidylinositol, and the growth of the recombinant strain was not affected, a possible toxic effect due to the activity of the enzyme was ruled out to explain the lack of expression of the synthetic gene encoding EF-PIPLC. A possible explanation is an unanticipated problem in the gene design that prevented its expression such as, for example, the formation of a secondary structure in the mRNA (Chandran et al. 2006; Menzella et al. 2005).

Both LS- and BC-PIPLCs were able to hydrolyze B-FLIP (Fig. 2). The B-FLIP assay provides a simple and reliable method for online monitoring PIPLC protein production in a fermentation process, as it takes less than $10 \mathrm{~min}$ to perform and it is done in aqueous solution (Fig. 2a). Although BCPIPLC showed higher catalytic activity in this aqueous assay, LS-PIPLC was more efficient in the oil degumming process. The same amount of enzyme was used for oil degumming (Fig. 2b), but considering the difference in molecular weight of the two proteins, $\sim 35 \mathrm{kDa}$ for BC-PIPLC and $\sim 45 \mathrm{kDa}$ for LS-PILPC, the latter had a lower molar concentration. LSPIPLC required a minimum concentration of $\sim 20 \mathrm{nM}$ to completely hydrolyze PI present in oil while BC-PLC required $\sim 30 \mathrm{nM}$. Such differential behaviors for a phospholipase enzyme between an aqueous and an oil environment have been previously observed for engineered PC-PLC enzymes (Castelli et al. 2016).
In order to develop a high-yield fermentation process for the production of LS-PIPLC, a typical fed-batch strategy using glycerol as carbon source was tested. Using a minimal medium, a final titer of $\sim 14 \mathrm{~g} / \mathrm{L}$ was obtained in $\sim 30 \mathrm{~h}$ post induction, which corresponds to a volumetric productivity of $\sim 0.50 \mathrm{~g} / \mathrm{L} \mathrm{h}$ (Fig. 3, Table 2). To the best of our knowledge, this is the highest titer ever reached for a soluble protein in $E$. coli cultures. The fermentation process also demonstrated to be robust, since different qualities of glycerol were successfully used with minor changes in protein productivity and cell growth. This result has a direct impact in the manufacturing costs of the enzyme and represents a remarkable contribution to facilitate the implementation of a cost-effective enzymatic degumming process (Simutis and Lubbert 2015).

In this work, it was also demonstrated that the combined use of both PLCs can hydrolyze up to $91 \%$ of the phospholipids present in crude oil (Fig. 5), reducing the volume of gums and incrementing the extra yield in oil recovery. Based on the results reported here and elsewhere (Castelli et al. 2016), and the standard costs for fermentation media and enzyme recovery at industrial scale (Peiru et al. 2015; Ravasi et al. 2015), we anticipate that the dose of PCPLC plus PIPLC to treat a ton of crude oil will be below $\$ 2$. Considering the current soybean oil price of about $\$ 750$ per ton, the extra yield reported here represents a gross benefit of $\$ 15$ per ton of treated oil. Moreover, taking into account the industrial conditions on which the enzymes are to be used and considering the low cost of enzyme manufacturing, there is no need to introduce further modifications in the process by, for example, immobilizing the enzymes. All in all, the production of these enzymes provides an appealing incentive for the adoption of this environmentally friendly process for degumming oil.

Acknowledgement This work was funded by Keclon SA. The authors wish to thank Luis Palacios and Ernesto Ventrici from Molinos Rio de la Plata and Hector Autino from Bunge Argentina, for providing oil samples.

\section{Compliance with ethical standards}

Conflict of interest The authors declare that they have no conflict of interest.

Ethical statement This article does not contain any studies with human participants or animals performed by any of the authors.

\section{References}

Altschul SF, Madden TL, Schäffer AA, Zhang J, Zhang Z, Miller W, Lipman DJ (1997) Gapped BLAST and PSI-BLAST: a new generation of protein database search programs. Nucleic Acids Res 25: 3389-3402. doi:10.1093/nar/25.17.3389

Balla T, Wymann M, York JD (2012) Phosphoinositides II: the diverse biological functions. Springer, Netherlands 
Birrell GB, Zaikova TO, Rukavishnikov AV, Keana JF, Griffith OH (2003) Allosteric interactions within subsites of a monomeric enzyme: kinetics of fluorogenic substrates of PI-specific phospholipase C. Biophys J 84:3264-3275. doi:10.1016/S0006-3495(03) 70051-4

Borrelli G, Trono D (2015) Recombinant lipases and phospholipases and their use as biocatalysts for industrial applications. Int J Mol Sci 16: 20774. doi:10.3390/ijms 160920774

Castelli ME, Menzella H, Peirú S, Vetcher L (2016) Compositions and methods for oil degumming. PCT/US16/42844

Chandran SS, Menzella HG, Carney JR, Santi DV (2006) Activating hybrid modular interfaces in synthetic polyketide synthases by cassette replacement of ketosynthase domains. Chem Biol 13:469-474. doi:10.1016/j.chembiol.2006.02.011

Clausen K (2001) Enzymatic oil-degumming by a novel microbial phospholipase. Eur J Lipid Sci Technol 103:333-340. doi:10.1002/14389312(200106)103:6<333::aid-ejlt333>3.0.co;2-f

Dijkstra AJ (2011) Enzymatic degumming. Lipid Technol 23:36-38. doi: 10.1002/lite.201100085

Griffith OH, Ryan M (1999) Bacterial phosphatidylinositol-specific phospholipase C: structure, function, and interaction with lipids. Biochim Biophys Acta 1441:237-254

Hammond EG, Johnson LA, Su C, Wang T, White PJ (2005) Soybean Oil. In: Shahidi F (ed) Bailey's industrial oil and fat products, Vol 2. Wiley, Hoboken, pp 557-654

Heinz DW, Ryan M, Bullock TL, Griffith OH (1995) Crystal structure of the phosphatidylinositol-specific phospholipase C from Bacillus cereus in complex with myo-inositol. EMBO J 14:3855-3863

Heinz DW, Ryan M, Smith MP, Weaver LH, Keana JFW, Griffith OH (1996) Crystal structure of phosphatidylinositol-specific phospholipase $C$ from Bacillus cereus in complex with glucosaminyl $(\alpha 1 \rightarrow 6)$ d-myo-inositol, an essential fragment of GPI anchors. Biochemistry 35:9496-9504. doi:10.1021/bi9606105

Kirk O, Borchert TV, Fuglsang CC (2002) Industrial enzyme applications. Curr Opin Biotechnol 13:345-351. doi:10.1016/S09581669(02)00328-2

Kuksis A (2003) Inositol phospholipid metabolism and phosphatidyl inositol kinases. Elsevier, Amsterdam

Lee SY (1996) High cell-density culture of Escherichia coli. Trends Biotechnol 14:98-105. doi:10.1016/0167-7799(96)80930-9

Loeffler F, Plainer H, Sproessler B, Ottofrickenstein H (1999) Vegetable oil enzymatic degumming process by means of Aspergillus phospholipase. PCT/DE1996/001190

Low MG (1989) The glycosyl-phosphatidylinositol anchor of membrane proteins. Biochim Biophys Acta 988:427-454. doi:10.1016/03044157(89)90014-2

Lyu Y, Ye L, Xu J, Yang X, Chen W, Yu H (2016) Recent research progress with phospholipase $\mathrm{C}$ from Bacillus cereus. Biotechnol Lett 38:23-31. doi:10.1007/s10529-015-1962-6
Menzella HG (2011) Comparison of two codon optimization strategies to enhance recombinant protein production in Escherichia coli. Microb Cell Factories 10:15. doi:10.1186/1475-2859-10-15

Menzella HG, Ceccarelli EA, Gramajo HC (2003) Novel Escherichia coli strain allows efficient recombinant protein production using lactose as inducer. Biotechnol Bioeng 82:809-817. doi:10.1002/bit.10630

Menzella HG, Reid R, Carney JR, Chandran SS, Reisinger SJ, Patel KG, Hopwood DA, Santi DV (2005) Combinatorial polyketide biosynthesis by de novo design and rearrangement of modular polyketide synthase genes. Nat Biotechnol 23:1171-1176. doi:10.1038/ nbt1128

Peiru S, Aguirre A, Eberhardt F, Braia M, Cabrera R, Menzella HG (2015) An industrial scale process for the enzymatic removal of steryl glucosides from biodiesel. Biotechnol Biofuels 8:223. doi: 10.1186/s13068-015-0405-X

Ravasi P, Braia M, Eberhardt F, Elena C, Cerminati S, Peiru S, Castelli ME, Menzella HG (2015) High-level production of Bacillus cereus phospholipase C in Corynebacterium glutamicum. J Biotechnol 216:142-148. doi:10.1016/j.jbiotec.2015.10.018

Sambrook J, Fritsch EF, Maniatis T (1989) Molecular cloning : a laboratory manual. Cold Spring Harbor Laboratory, New York

Segers J, van der Sande R (1990) Degumming - theory and practice. In: Erickson HD R (ed) Proceedings of the World conference on edible fats and oils processing: basic principles and modern practices. AOCS, Champaign, pp 88-93

Simutis R, Lubbert A (2015) Bioreactor control improves bioprocess performance. Biotechnol J 10:1115-1130. doi:10.1002/biot. 201500016

Smrcka AV, Brown JH, Holz GG (2012) Role of phospholipase C epsilon in physiological phosphoinositide signaling networks. Cell Signal 24:1333-1343. doi:10.1016/j.cellsig.2012.01.009

Søe JB, Turner M (2012) Enzymatic oil-degumming method. US 11/623,689

Su X, Schmitz G, Zhang M, Mackie RI, Cann IKO (2012) Chapter oneheterologous gene expression in filamentous fungi. In: Geoffrey MG, Sima S (eds) Advances in applied microbiology. Academic Press, Waltham, pp 1-61

Sumner JB (1944) A method for the colorimetric determination of phosphorus. Science 100:413-414. doi:10.1126/science.100.2601.413

Ward OP (2012) Production of recombinant proteins by filamentous fungi. Biotechnol Adv 30:1119-1139. doi:10.1016/j.biotechadv.2011. 09.012

Welch M, Govindarajan S, Ness JE, Villalobos A, Gurney A, Minshull J, Gustafsson C (2009) Design parameters to control synthetic gene expression in Escherichia coli. PLoS One 4:e7002. doi:10.1371/ journal.pone. 0007002

Yang B, Zhou R, Yang J-G, Wang Y-H, Wang W-F (2008) Insight into the enzymatic degumming process of soybean oil. J Am Oil Chem Soc 85:421-425. doi:10.1007/s11746-008-1225-y 